\title{
Clinical significance of androgen secretion disorders in men with a malignancy
}

\author{
Pawel J. Wiechno ${ }^{1}$ - Grazyna M. Poniatowska ${ }^{1}$ - Wojciech Michalski ${ }^{1}$. \\ Jakub Kucharz ${ }^{1,2}$ (D) Malgorzata Sadowska ${ }^{1}$. Joanna Jonska-Gmyrek ${ }^{1}$. \\ Karol Nietupski ${ }^{1} \cdot$ Joanna Rzymowska $^{1}$. Tomasz Demkow ${ }^{1}$
}

Received: 11 May 2017/Accepted: 24 May 2017/Published online: 1 June 2017

(c) The Author(s) 2017. This article is an open access publication

\begin{abstract}
Cancer and its treatment can lead in men to testosterone deficiency, accompanied by somatic and mental symptoms. Germ cell tumours and their treatment may disturb the pituitary-gonadal axis, hence leading to significant clinical abnormalities. In some prostate cancer patients, castration, temporary or permanent, is a desired therapeutic condition. Yet, it is burdened with various side effects of complex intensity and significance. Last but not least, patients in the terminal stage of a malignancy present with low testosterone concentrations as a part of anorexiacachexia syndrome. Oncological management of such patients disturbs their homeostasis, androgen metabolism included, which results in numerous complications and worsens their quality of life. In the present paper, we analysed the frequency and sequelae of testosterone deficiency in some clinical scenarios, on the basis of original papers, meta-analyses and reviews available in PubMed. Androgen secretion disorders in male cancer patients depend on a cancer type, stage and methods of treatment. Number of testicular cancer survivors is increasing, and as a consequence, more patients cope with late complications, testosterone deficiency included. Hormone therapy in prostate cancer patients significantly prolongs survival, and then numerous men experience long-term adverse effects of androgen deficiency. Those, in turn, particularly the
\end{abstract}

Jakub Kucharz

jakub.kucharz@uj.edu.pl

1 Department of Uro-Oncology, Maria Sklodowska-Curie Memorial Cancer Center and Institute of Oncology, Roentgena 5 st, 02-781 Warsaw, Poland

2 Department of Experimental and Clinical Surgery, Jagiellonian University Medical College, Michalowskiego 12 st, Kraków, Poland metabolic syndrome, may contribute to increased mortality. Androgen deficiency is a part of cancer anorexiacachexia syndrome. The role of androgen deficiency in cancer patients is still under debate, and further studies are urgently needed to establish appropriate clinical guidelines.

Keywords Testosterone - Hypogonadism - Testicular cancer $\cdot$ Prostate cancer $\cdot$ Metastatic cancer

\section{Introduction}

Hypogonadism in men is defined as clinical symptoms resulting from androgen deficiency [1,2]. Diagnosis of testosterone deficiency remains a challenge. Various reference values are presented in the literature data. It is agreed that testosterone deficiency is unequivocal in case of total serum testosterone below $8 \mathrm{nmol} / \mathrm{L}$. In such cases, hormone replacement therapy is recommended unless contraindicated. Total testosterone concentration of 8-12 nmol/L accompanied by clinical symptoms of testosterone deficiency is a rationale for commencing test supplementation [3]. Threshold values in different units of testosterone concentration are presented in Fig. 1.

The frequency of androgen deficiency increases with age; the postulated testosterone decrease in adult men is 0.4-2.0\% per annum [4].

Testosterone exerts an endocrine effect on target organs but also has paracrine and autocrine effects on testicular tissue, hence regulating spermatogenesis [5]. Impaired androgen activity in postpubertal men may lead to infertility, sexual disorders, muscular weakness, increased fatty tissue mass, bone demineralisation, metabolic disorders and haematopoiesis impairment [6, 7]. Physiological testosterone concentrations have a beneficial effect on 


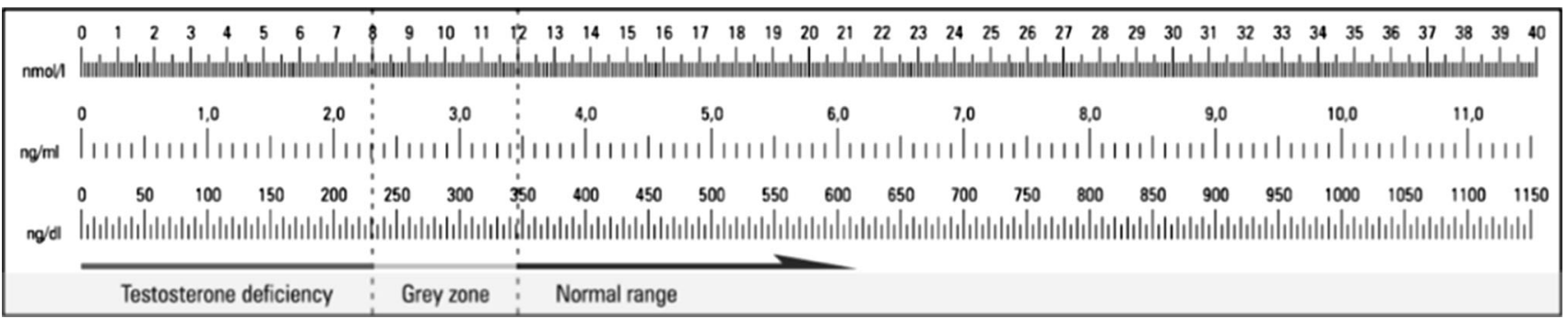

Fig. 1 Threshold values in different units of testosterone concentration

metabolism, and low testosterone can be linked with metabolic syndrome [8]. Diagnostic criteria of metabolic syndrome are presented in Table 1 [9].

Hormonal receptors of the hypothalamus-pituitary-gonadal axis can be identified in various areas of the male brain. Sex hormones affect numerous cerebral structures, especially the hippocampus, amygdaloid body and the prefrontal cortex $[10,11]$. As a result, apart from obvious changes in sexual behaviour, androgen deficiency leads to a higher anxiety level, prevalence of depression and impaired cognitive functions.

In summary, normal androgen concentrations are crucial for men's well-being. Health, according to the World Health Organisation, is a state of 'physical, mental and social well-being, not merely the absence of disease or infirmity'.

\section{Materials and methods}

In this paper, we analysed articles published in PubMed, using the following keywords: 'low testosterone level', 'hypogonadism', 'testicular germ cell tumour', 'prostate cancer', 'androgen deprivation therapy (ADT)', 'side effects', 'metastatic cancer', 'cachexia' and 'testosterone'. In addition, we analysed the guidelines published by American Association of Clinical Endocrinologists (AACE), European Association of Urology (EAU) and

Table 1 Diagnostic criteria for metabolic syndrome according to National Cholesterol Education Program Adult Treatment Panel III (NCEPATP III), 2001, International Diabetes Federation (IDF) and JIS - collaborative definition of IDF, AHA, NHLBI, WHF and IAS, 2009

\begin{tabular}{|c|c|c|c|}
\hline & NCEP-ATP III & IDF & JIS \\
\hline \multirow[t]{2}{*}{ Arterial hypertension } & Systolic BP $\geq 130 \mathrm{mmHg}$ & Systolic BP $\geq 130 \mathrm{mmHg}$ & Systolic BP $\geq 130 \mathrm{mmHg}$ \\
\hline & $\begin{array}{l}\text { Diastolic } \mathrm{BP} \geq 85 \mathrm{mmHg} \text { or treated } \\
\text { hypertension }\end{array}$ & $\begin{array}{l}\text { Diastolic } \mathrm{BP} \geq 85 \mathrm{mmHg} \text { or treated } \\
\text { hypertension }\end{array}$ & $\begin{array}{l}\text { Diastolic } \mathrm{BP} \geq 85 \mathrm{mmHg} \text { or treated } \\
\text { hypertension }\end{array}$ \\
\hline Obesity & $\begin{array}{l}\text { Waist circumference } \geq 88 \mathrm{~cm} \text { in } \\
\text { women and } \geq 102 \mathrm{~cm} \text { in men }\end{array}$ & $\begin{array}{l}\text { Waist circumference } \geq 80 \mathrm{~cm} \text { in } \\
\text { women and } \geq 94 \mathrm{~cm} \text { in men or BMI } \\
>30 \mathrm{~kg} / \mathrm{m}^{2}\end{array}$ & $\begin{array}{l}\text { Waist circumference } \geq 80 \mathrm{~cm} \text { in } \\
\text { women and } \geq 94 \mathrm{~cm} \text { in men }\end{array}$ \\
\hline Insulin resistance & $\begin{array}{l}\text { Fasting plasma glucose } \geq 6.1 \mathrm{mmol} / \mathrm{l} \\
\quad(110 \mathrm{mg} / \mathrm{dl})\end{array}$ & $\begin{array}{l}\text { Fasting plasma glucose } \geq 5.6 \mathrm{mmol} / \mathrm{l} \\
\quad(100 \mathrm{mg} / \mathrm{dl})\end{array}$ & $\begin{array}{l}\text { Fasting plasma glucose } \geq 5.6 \mathrm{mmol} / \mathrm{l} \\
(100 \mathrm{mg} / \mathrm{dl}) \text { or pharmacological } \\
\text { treatment of type II diabetes mellitus }\end{array}$ \\
\hline Dyslipidaemia & $\begin{array}{l}\text { HDL-C }<1.03 \mathrm{mmol} / \mathrm{L}(40 \mathrm{mg} / \mathrm{dl}) \text { in } \\
\text { men and }<1.3 \mathrm{mmol} / 1(50 \mathrm{mg} / \mathrm{dl}) \text { in } \\
\text { women or treatment with statins }\end{array}$ & $\begin{array}{l}\mathrm{HDL}-\mathrm{C}<1.03 \mathrm{mmol} / \mathrm{L}(40 \mathrm{mg} / \mathrm{dl}) \text { in } \\
\text { men and }<1.3 \mathrm{mmol} / 1(50 \mathrm{mg} / \mathrm{dl}) \text { in } \\
\text { women or treatment with statins }\end{array}$ & $\begin{array}{c}\text { HDL-C }<1.03 \mathrm{mmol} / \mathrm{L}(40 \mathrm{mg} / \mathrm{dl}) \text { in } \\
\text { men and }<1.3 \mathrm{mmol} / 1(50 \mathrm{mg} / \mathrm{dl}) \text { in } \\
\text { women or dyslipidaemia treatment }\end{array}$ \\
\hline Hypertriglyceridemia & $\begin{array}{l}\text { Triglycerides }>1.7 \mathrm{mmol} / 1(150 \mathrm{mg} / \\
\text { dl) or hypertriglyceridemia } \\
\text { treatment }\end{array}$ & $\begin{array}{l}\text { Triglycerides }>1.7 \mathrm{mmol} / \mathrm{l}(150 \mathrm{mg} / \\
\text { dl) or hypertriglyceridemia } \\
\text { treatment }\end{array}$ & $\begin{array}{l}\text { Triglycerides }>1.7 \mathrm{mmol} / \mathrm{l}(150 \mathrm{mg} / \\
\text { dl) or hypertriglyceridemia treatment }\end{array}$ \\
\hline Metabolic syndrome & $\geq 3$ criteria & Obesity and $\geq 2$ other criteria & $\geq 3$ criteria \\
\hline
\end{tabular}

NCEP-ATP III National Cholesterol Education Program Adult Treatment Panel III, 2001, IDF International Diabetes Federation, JIS metabolic syndrome definition according to consensus of IDF, NHLB Institute National Heart, Lung and Blood Institute, AHA American Heart Association, $W H F$ World Heart Federation, IAS International Atherosclerosis Society and IAS Obesity, 2009, BP blood pressure, $H D L-C$ High-Density Lipoprotein Cholesterol 
European Society for Medical Oncology (ESMO) regarding testosterone deficiency in cancer patients.

\section{Testosterone deficiency in selected clinical situations}

\section{Germ cell tumours}

Germ cell tumours account for the majority of testicular malignancies. The incidence peaks in the age group of $15-36$ and is still rising [12]. In view of the excellent outcomes, the interest shifts to late and chronic negative sequelae of the disease and its treatment.

The risk of decreased testosterone concentration years after successful treatment of germ cell tumours mounts even to 25\% [13-22]. Table 2 shows the risk of testosterone deficiency in this group of patients.

The total testosterone deficiency in men after unilateral orchiectomy for germ cell tumours tends to attenuate over time [13-22]. The concentrations return to normal limits as soon as 2 years after treatment [15] and after 10 years do not differ from those observed in the healthy population. However, a more frequent finding is the so-called compensated hypogonadism, i.e. elevated luteinising hormone (LH) with normal testosterone levels; this can be observed in $75 \%$ patients. The reported incidence of compensated hypogonadism is presented in Table 3 .

All authors report on the chronic nature of compensated hypogonadism [13-20], diagnosed even 10 years after the completion of treatment [14]. LH concentration is regarded as a better indicator of hormonal changes many years after unilateral orchiectomy $[14,16,19,20,24,25]$.
Lowering the testosterone/LH ratio may reflect the decrease in testicular volume; however, the progressive decrease in this ratio may be a sign of Leydig cell damage $[14,26]$. This, in turn, results from exposure to cisplatin, the main cytotoxic agent used in germ cell tumours treatment $[16,20]$. Nevertheless, orchiectomy remains the principal cause of this disorder [13]. The hormonal alterations reflect the accelerated ageing of the pituitary-testicular axis.

Testicular cancer survivors often present with overweight, hypercholesterolaemia, arterial hypertension (24, 24 and $30 \%$, respectively). $25 \%$ of patients fulfil the criteria of metabolic syndrome. Testosterone concentration below $15 \mathrm{nmol} / \mathrm{l}$ ( $22 \%$ patients) proved to be associated with a higher risk of metabolic syndrome (OR 4.1, 95\% CI 1.8-9.3) [27]. Relative risk (HR) of metabolic syndrome in testicular cancer survivors in comparison with the healthy population was 1.9 , or even higher in patient receiving chemotherapy (HR 2.2 according to NCEP-ATP criteria and 2.3-IDF criteria). Similarly, a highest risk was seen in patients within the lowest testosterone quartile (HR 2.5) [28]. Particularly concerning is the 3.1-fold increase in the risk of myocardial infarction. The risk of cardiovascular complications is clearly related to methods of postorchiectomy treatment, i.e. chemo- and radiotherapy [28, 29].

In germ cell tumour patients, a negative impact of hypogonadism on the quality of life after unilateral orchiectomy was confirmed by Huddart [23]. Disorders of the pituitary-testicular axis negatively affect physical wellbeing, sexual functions and mood [20]. However, other authors do not confirm the effect of testosterone deficiency on mood and anxiety levels [30]. The sole decrease in

Table 2 Testosterone deficiency in testicular cancer patients after completion of treatment

\begin{tabular}{|c|c|c|c|c|}
\hline Study & $\begin{array}{l}\text { Number of } \\
\text { patients }(n)\end{array}$ & $\begin{array}{l}\text { Threshold for testosterone } \\
\text { (T) concentration (LLN) }\end{array}$ & $\begin{array}{l}\text { Median } T \text { concentration } \\
\text { after the treatment }\end{array}$ & $\begin{array}{l}\text { Percentage of patients with } \\
\text { testosterone deficiency }(\%)\end{array}$ \\
\hline Pühse et al. [13] & 160 & $9.85 \mathrm{nmol} / \mathrm{L}$ & NA & $11-33$ \\
\hline Nord et al. [14] & 1183 & $8 \mathrm{nmol} / \mathrm{L}$ & $16.7(14.8-18.7) \mathrm{nmol} / \mathrm{L}$ & NA \\
\hline Eberhard et al. [15] & 143 & $10 \mathrm{nmol} / \mathrm{L}$ & $13(3-22) \mathrm{nmol} / \mathrm{L}$ & NA \\
\hline Berger et al. [16] & 63 & $3 \mathrm{ng} / \mathrm{mL}$ & $5(1.5-11.1) \mathrm{ng} / \mathrm{ml}$ & 17 \\
\hline Gerl et al. ${ }^{\mathrm{a}}[17]$ & 117 & $10 \mathrm{nmol} / \mathrm{L}$ & $16.3(6.0-55.7) \mathrm{nmol} / \mathrm{L}$ & 11 \\
\hline Lackner et al. [18] & 83 & $3 \mathrm{ng} / \mathrm{mL}$ & NA & 25.3 \\
\hline Ondrusova et al. [19] & 823 & $12 \mathrm{nmol} / \mathrm{L}$ & NA & 15.1 \\
\hline Wiechno et al. [20] & 326 & $2.6 \mathrm{ng} / \mathrm{mL}$ & $0.2-11.8 \mathrm{ng} / \mathrm{mL}$ & 15 \\
\hline O'Carrigan et al. [21] & 54 & $8 \mathrm{nmol} / \mathrm{L}$ & $13 \mathrm{nmol} / \mathrm{L}$ & 13 \\
\hline Willemse et al. ${ }^{\mathrm{b}}$ [22] & $176^{\mathrm{b}}$ & $8 \mathrm{nmol} / \mathrm{L}$ & $6.4-32.1 \mathrm{nmol} / \mathrm{L}$ & 17.6 \\
\hline
\end{tabular}

$T$ testosterone, $L L N$ lower limit of normal, $N A$ not available

a Patients undergoing surgery with subsequent chemotherapy, with cumulative cisplatin dose of max. $400 \mathrm{mg} / \mathrm{m}^{2}$, median values

b Patients undergoing combination chemotherapy, hypogonadism defined as $T<10 \mathrm{nmol} / \mathrm{L}$ 
Table 3 Compensated hypogonadism in testicular cancer patients after completion of treatment

\begin{tabular}{|c|c|c|c|c|}
\hline Study & $\begin{array}{l}\text { Number of } \\
\text { patients }(n)\end{array}$ & $\begin{array}{l}\text { Threshold for testosterone } \\
(T) \text { concentration (LLN) }\end{array}$ & $\begin{array}{l}\text { Threshold for LH } \\
\text { concentration (ULN) }\end{array}$ & $\begin{array}{l}\text { Percentage of patients with overt } \\
(T<\text { LLN)/compensated hypogonadism } \\
(T>\text { LLN and LH }>\text { ULN)/total }\end{array}$ \\
\hline Pühse et al. [13] & 160 & $9.85 \mathrm{nmol} / \mathrm{L}$ & $8.95 \mathrm{mU} / \mathrm{mL}$ & NA/NA/NA \\
\hline Nord et al. ${ }^{\mathrm{a}}[14]$ & 373 & $8 \mathrm{nmol} / \mathrm{L}$ & $12 \mathrm{IU} / \mathrm{L}$ & NA/NA/19\% \\
\hline $\begin{array}{l}\text { Eberhard et al. } \\
\text { [15] }\end{array}$ & 143 & $10 \mathrm{nmol} / \mathrm{L}$ & $10 \mathrm{IU} / \mathrm{L}$ & NA/NA/37\% \\
\hline Berger et al. [16] & 63 & $3 \mathrm{ng} / \mathrm{mL}$ & 15 & $10 \% / 24 \% / \mathrm{NA}$ \\
\hline Gerl et al. ${ }^{\mathrm{b}}$ [17] & 117 & $10 \mathrm{nmol} / \mathrm{L}$ & $8 \mathrm{IU} / \mathrm{L}$ & $11 \% / 19 \% / \mathrm{NA}$ \\
\hline Lackner et al. [18] & 83 & $3 \mathrm{ng} / \mathrm{mL}$ & $6.9 \mathrm{mU} / \mathrm{mL}$ & NA/NA/26.5\% \\
\hline $\begin{array}{l}\text { Ondrusova et al. } \\
\text { [19] }\end{array}$ & 823 & $12 \mathrm{nmol} / \mathrm{L}$ & $8.2 \mathrm{mIU} / \mathrm{mL}$ & $15 \% / 15.1 \% / \mathrm{NA}$ \\
\hline $\begin{array}{l}\text { Wiechno et al. } \\
\text { [20] }\end{array}$ & 326 & $2.6 \mathrm{ng} / \mathrm{mL}$ & $6.1 \mathrm{mIU} / \mathrm{mL}$ & $15 \% / 55 \% / \mathrm{NA}$ \\
\hline $\begin{array}{l}\text { O'Carrigan et al. } \\
\text { [21] }\end{array}$ & 54 & $8 \mathrm{nmol} / \mathrm{L}$ & NA & $13 \% / \mathrm{NA} / 33 \%$ \\
\hline $\begin{array}{l}\text { Willemse et al. }^{\mathrm{c}} \\
\text { [22] }\end{array}$ & $176^{\mathrm{b}}$ & $8 \mathrm{nmol} / \mathrm{L}$ & $10 \mathrm{IU} / \mathrm{L}$ & NA/NA/17.6\% \\
\hline Huddart et al. [23] & 272 & $10 \mathrm{ng} / \mathrm{mL}$ & $12 \mathrm{IU} / \mathrm{L}$ & $15 \% / 13 \% / \mathrm{NA}$ \\
\hline
\end{tabular}

$T$ testosterone, $L L N$ lower limit of normal, $U L N$ upper limit of normal, $N A$ not available

a Patients undergoing chemotherapy, with cumulative cisplatin dose of max. $850 \mathrm{mg} / \mathrm{m}^{2}$

b Patients undergoing surgery with subsequent chemotherapy, with cumulative cisplatin dose of max. $400 \mathrm{mg} / \mathrm{m}^{2}$, median values

c Patients undergoing combination chemotherapy, hypogonadism defined as $T<10 \mathrm{nmol} / \mathrm{L}$

testosterone concentration after unilateral orchiectomy does not necessarily worsen sexual functions $[18,20]$.

Since impaired androgen metabolism may negatively affect somatic and mental status of testicular cancer survivors, the question of testosterone supplementation arises. Recovering physiological testosterone concentrations increases the muscular mass and strength, increases bone mineralisation and the lean body mass, decreases the waist circumference and insulin resistance as well as improves lipid metabolism [31-35]. Testosterone supplementation improves sexual functions in hypogonadic men [36] as well as alleviates depression and cognitive disorders [37, 38]. However, there is a lack of studies assessing effects of testosterone supplementation after unilateral orchiectomy. It is unclear when androgen supplementation should be commenced or whether it should be maintained for decades of the survivors' lives, especially in view of the tendency of testosterone deficiency to attenuate over time.

\section{Prostate cancer}

Prostate cancer is a classic example of an androgen-dependent malignancy. Metastatic and symptomatic disease is a typical indication for castration, surgical or pharmacological. Disseminated prostate cancer requires continuous androgen ablation $[39,40]$. Long life expectancy in this group ensures a long-term therapeutic benefit but at the cost of adverse effects. In patients qualified for radical radiotherapy, hormone therapy must be added as adjuvant treatment in high-risk patients (for 2-3 years) and may be considered in intermediate-risk patients (for 6 months) $[39,40]$.

The risk of metabolic syndrome in prostate cancer patients undergoing hormone therapy exceeds $50 \%$ and is significantly higher in comparison with the control group $[41,42]$. The frequency of metabolic syndrome in prostate cancer patients not receiving hormone therapy is $22 \%$, whereas in androgen-deprived patients is as high as 55\% [41]. Prostate cancer patients also present with higher serum glucose concentrations in comparison with the control group [41]. In an analysis of 37,443 men with prostate cancer undergoing treatment with LH-RH analogues, the relative risk of diabetes was 1.44 [43]. A decrease in testosterone concentration leads to an increase in fasting insulin and low-density lipoproteins (LDL) as early as 3 months after androgen deprivation therapy (ADT) commencement. Moreover, serum glucose, total cholesterol and high-density lipoproteins (HDL) increase 1 year later, accompanied by increasing waist circumference [44] and triglycerides concentration [45]. According to a meta-analysis, the relative risk of metabolic syndrome and diabetes in men undergoing ADT is 1.75 and 1.36, respectively [46]. ADT-driven abnormalities, in opposition to the typical metabolic syndrome, include a tendency to 
subcutaneous fat deposits and high-density lipoproteins (HDL) increase [44, 47]. This syndrome is associated with a 3-fold increase in cardiovascular diseases incidence [41] as well as with type II diabetes.

The relationship between cardiovascular system and ADT remains a matter of controversy. ADT leads to a poorer control of arterial hypertension [48, 49], although short-term treatment does not necessarily increase blood pressure values [47]. A $20 \%$ increase in the risk of serious cardiovascular diseases along with a significant increase in fatal incidents (HR 2.6) has been reported [50]. The literature data also suggest an increased risk of myocardial infarctions, sudden cardiac deaths and life-threatening ventricular arrhythmias [43]. However, contradictory reports also exist, suggesting a lack of association between ADT and myocardial infarctions and sudden deaths [51] as well as increased mortality due to cardiovascular conditions [52-54]. A meta-analysis of 8 randomised trials did not confirm a relation between either short-term ADT ( $<6$ months) or long-term ADT ( $>3$ years) and an increased risk of cardiovascular complications [55]. The majority of prostate cancer patients have a history of metabolic or cardiovascular disorders, or at least risk factors predisposing to diabetes or cardiovascular diseases, present before the diagnosis of malignancy. In these patients, ADT with gonadotropin-releasing hormone $(\mathrm{GnRH})$ antagonists is less likely to result in cardiovascular incidents than GnRH agonists [56].

According to current guidelines, patients undergoing ADT should be monitored for lipid disorders and glucose intolerance. Consulting a cardiologist should be considered in patients with the aforementioned comorbidities or aged over 65 [40]. To prevent metabolic complications, a healthy lifestyle (i.e. smoking cessation, maintaining a proper body weight, physical activity) is advised. A meta-analysis of trials assessing physical exercise revealed an improvement in patients' body constitution and quality of life [57]. When metabolic complications or cardiovascular disorders occur, statins, hypoglycaemising agents, acetylsalicylic acid or hypotensive medications are used. Metformin, introduced gradually up to the dose of $850 \mathrm{mg}$ twice daily and combined with lifestyle factors, may ameliorate the body constitution and cardiovascular status [58].

Maintaining castration in men leads to a progressive loss of bone mass and this, in turn, to an increased risk of pathological fractures [59]. Prior to ADT, only $19.4 \%$ men present with normal bone density; risk of osteoporosis in this group equals $35.4 \%$. In the course of treatment, the osteoporosis risk increases to $49.2 \%$ after 2 years and further to $80.6 \%$ after 10 years [60]. Bone density monitoring, lifestyle modifications (i.e. physical exercise, smoking cessation, weight reduction, avoiding alcohol consumption) and supplementation of calcium (1500 mg daily) and vitamin D (800 IU daily) are therefore recommended. Zoledronic acid is capable of inhibiting bone loss [61] and is labelled for use in patients with skeletal metastases. Denosumab, administered at the dose of $120 \mathrm{mg}$ every 4 weeks, proved more effective in preventing skeletal-related events (SRE) in patients with bone metastases [62]. Moreover, on the basis of clinical trials, denosumab has been approved for preventing bone loss in men undergoing ADT (60 mg every 6 months) [63].

On ADT, haemoglobin concentration in men with nonmetastatic prostate cancer is gradually decreasing, usually by $1-2 \mathrm{~g} / \mathrm{dL}[64,65]$. In most cases, anaemia is mild and does not worsen quality of life, hence not requiring an intervention [66]. Significant anaemia usually implies cancer progression or is associated with adverse effects of treatment. Management of profound anaemia is a complex problem, beyond the scope of this paper.

$80 \%$ of ADT patients present with hot flushes; $27 \%$ of these consider this symptom the most disturbing side effect, which may continue even after ADT completion $[67,68]$. Hot flushes tend to be more pronounced in younger men, with a lower body mass index (BMI). Their intensity is affected by polymorphism in genes encoding agents responsible for vasoconstriction, immunological response, circadian rhythms and neurotransmission [69]. Management of hot flushes includes hormonal agents, e.g. megestrol acetate, medroxyprogesterone acetate, diethylstilbestrol and cyproterone acetate [70]. According to a randomised clinical trial, venlafaxine is less effective than hormonal medications [71]. Gabapentin administered at bedtime has proved to reduce intensity of hot flushes and night drenching sweats [72].

Prostate cancer patients undergoing ADT often report growing fatigue (compared to patients without ADT), further exacerbated by comorbidities $[73,74]$. Fatigue, in turn, may lead to depression [75, 76]. ADT adverse events are associated with depression and anxiety [75, 76]. Cognitive impairment as early as after 6 months of treatment has been reported [76], although some authors did not confirm these results [76, 77]. A meta-analysis of fourteen trials only revealed deficits in visual-motor tasks [78]. ADT increases the risk of depression by $23 \%$ as well as frequency of hospitalisations and ambulatory psychiatric consultations [79]. Sexual functions are disabled even after a short-term adjuvant treatment [77, 80]. ADT leads to decreased libido and sex activity as well as lowered sense of masculinity which progresses up to 9 months of treatment. Intermittent ADT may restore sexual activity in 52\% of patients who were active before the treatment [81]. Sexual disorders may result in relationship problems and quality of life impairment. Therefore, patients scheduled for ADT should be informed about potential adverse effects and offered psychological support [82]. 
Intermittent ADT was introduced to limit adverse effects in palliative patients. According to the European Association of Urology (EAU), intermittent ADT does not worsen overall survival (OS); the treatment costs are lower and adverse effects less frequent. This opinion is based on results of a meta-analysis (2014) [83]. Contrarily, European Society for Medical Oncology (ESMO) does not recommend intermittent ADT in metastatic prostate cancer patients as the trial designed to prove non-inferiority of such approach to continuous ADT gave negative results [84].

Hormone replacement therapy attenuates symptoms of hypogonadism, hence improving the quality of life. Despite historical controversies, such treatment may now be regarded safe in patients without an active cancer, given that recurrence risk is low [55].

\section{Metastatic cancer and cachexia syndrome}

According to the WHO data, the overall cancer mortality in men in the world and in Europe is 7,410,000 and 716,000, respectively. Hence, a significant number of patients are bound to experience a terminal stage of their diseases [85].

Androgen disorders are observed in the majority of men with a metastatic cancer [86] and even in 90\% patients treated with opioids for disease-related symptoms [87]. Their intensity is particularly high in patients with cachexia syndrome [88]. The concentrations of bioavailable testosterone in men with advanced malignancies were proved lower than in the control group; prostate cancer patients were excluded from the analysis. Moreover, decreased testosterone levels were associated with a significant increase in LH concentration. Such results suggest testicular insufficiency in the terminal stage of malignancies [89].

Opioid administration is also related to androgen deficiency [86, 87, 90], as their mode of action involves delta receptors localised on GnRH-secreting neurons [91]. This, in turn, inhibits the pituitary-gonadal axis, hence decreasing the testosterone secretion [92].

Alkylating agents, platinum compounds included, also impair the gonads and their secretory functions [93].

Additionally, high concentrations of inflammatory cytokines (e.g. interleukin-6) observed in advanced malignancies inhibit the pituitary-gonadal axis, hence increasing androgen deficiency. Similar abnormalities may be due to altered concentrations of polypeptides regulating the energy homeostasis [89, 94].

Androgen deficiency also leads to appetite loss [89], thus forming a vicious circle and exacerbating the cachexia syndrome. Low concentrations of free testosterone are associated with weight loss and shorter overall survival in men with pancreatic cancer [90]. The relationship between low testosterone concentrations and negative survival prognosis has been confirmed by other authors [86]. Men with advanced cancers and androgen deficiency present with fatigue, anxiety, impaired well-being, a worse performance status according to Eastern Cooperative Oncology Group (ECOG), appetite loss and increased inflammatory parameters $[86,88]$. In summary, androgen deficiency plays an important role in complex disorders accounting for cancer cachexia syndrome. Nevertheless, the data regarding testosterone supplementation in this group are sparse. According to available literature, androgens in the management of cachexia syndrome seem less effective than either dexamethasone or megestrol acetate $[95,96]$. On the other hand, in a placebo-controlled randomised clinical trial, androgen supplementation inhibited inflammatory processes in hypogonadic men [97]. Since inflammation contributes to cachexia syndrome, further studies on androgen supplementation are warranted.

\section{Conclusions}

Androgen secretion disorders in male cancer patients depend on a cancer type, stage and methods of treatment.

Germ cell tumours are managed with radical intent; hence, the number of survivors is increasing. As a consequence, more patients cope with late complications, testosterone deficiency included. The principals of testosterone deficiency management are still to be established.

Hormone therapy in prostate cancer patients significantly prolongs survival, which makes many of them experience long-term adverse effects of androgen deficiency. Those, in turn, particularly the metabolic syndrome, may contribute to increased mortality. Proper prophylaxis and treatment of those adverse events should be seen as a part of clinical practice.

Androgen deficiency is a part of cancer anorexiacachexia syndrome. The role of androgen supplementation in this group of patients is still under debate.

\section{Compliance with ethical standards}

Conflict of interest The authors declare that they have no conflict of interest.

Ethical approval This article does not contain any studies with human participants or animals performed by any of the authors.

Open Access This article is distributed under the terms of the Creative Commons Attribution 4.0 International License (http://crea tivecommons.org/licenses/by/4.0/), which permits unrestricted use, distribution, and reproduction in any medium, provided you give appropriate credit to the original author(s) and the source, provide a link to the Creative Commons license, and indicate if changes were made. 


\section{References}

1. American Association of Clinical Endocrinologists. Medical guidelines for clinical practice for the evaluation and treatment of hypogonadism in adult male patients: 2002 update. Endocr Pract. 2002;8:440-56.

2. American Society of Andrology. Investigation, treatment, and monitoring of late-onset hypogonadismin males: ISA, ISSAM, EAU, EAA, and ASA recommendations. Eur Urol. 2009;55:121-30.

3. Anawalt BD, Hotaling JM, Walsh TJ, Matsumoto AM. Performance of total testosterone measurement to predict free testosterone for the biochemical evaluation of male hypogonadism. J Urol. 2012;187:1369-73.

4. Kaufman JM, Vermeulen A. The decline of androgen levels in elderly men and its clinical and therapeutic implications. Endocr Rev. 2005;26:833-76.

5. Zhang C, Yeh S. Chen YT I wsp: oligozoospermia with normal fertility in male mice lacking the androgen receptor in testis peritubular myoid cells. Proc Natl Acad Sci. 2006;103:17718-23.

6. Singh R, Artaza JN, Taylor WE, et al. Androgens stimulate myogenic differentiation and inhibit adipogenesis in C3H 10T1/2 pluripotent cells through an androgen receptor-mediated pathway. Endocrinology. 2003;144:5081.

7. Spivak JL. The blood in systemic disorders. Lancet. 2000;355:1707-12.

8. Boyanov MA, Boneva Z, Christov VG. Testosterone supplementation in men with type 2 diabetes, visceral obesity and partial androgen deficiency. Aging Male. 2003;6:1.

9. Szczeklik A et al. Evidence-based textbook of internal medicine-Szczeklik's Internal Medicine 2012; p. 1360.

10. Janowsky JS. Thinking with your gonads: testosterone and cognitive. Trends Cog Sci. 2006;10:77-82.

11. Tirassa P, Thilbin I, Angren G, et al. High-dose anabolic androgenic steroids modulate concentrations of nerve growth factor and expression of its low affinity receptor in male rat brain. J Neurosci Res. 1997;47:198-207.

12. Shanmugalingam T, Soultati A, Chowdhury S, Rudman S, Van Hemelrijck M. Global incidence and outcome of testicular cancer. Clin Epidemiol. 2013;5:417-27.

13. Pühse G, Secker A, Kemper S, Hertle L, Kliesch S. Testosterone deficiency in testicular germ-cell cancer patients is not influenced by oncological treatment. Int J Androl. 2011;34:e351-7.

14. Nord C, Bjøro T, Ellingsen D, et al. Gonadal hormones in longterm survivors 10 years after treatment for unilateral testicular cancer. Eur Urol. 2003;44:322-8.

15. Eberhard J, Ståhl O, Cwikiel M, Cavallin-Ståhl E, Giwercman Y, Salmonson EC, Giwercman A. Risk factors for post-treatment hypogonadism in testicular cancer patients. Eur J Endocrinol. 2008;158:561-70.

16. Berger CC, Bokemeyer C, Schuppert F, Schmoll HJ. Endocrinological late effects after chemotherapy for testicular cancer. Br J Cancer. 1996;73:1108-14.

17. Gerl A, Muhlbayer D, Hansmann G, Mraz W, Hiddemann W. The impact of chemotherapy on Leydig cell function in long term survivors of germ cell tumors. Cancer. 2001;91:1297-303.

18. Lackner JE, Koller A, Schatzl G, Marberger M, Kratzik C. Androgen deficiency symptoms in testicular cancer survivors are associated with sexual problems but not with serum testosterone or therapy. Urology. 2009;74:825-9.

19. Ondrusova M, Ondrus D, Dusek L, Spanikova B. Damage of hormonal function and bone metabolism in long-term survivors of testicular cancer. Neoplasma. 2009;56:473-9.

20. Wiechno P, Demkow T, Kubiak K, Sadowska M, Kamińska J. The quality of life and hormonal disturbances in testicular cancer survivors in Cisplatin era. Eur Urol. 2007;52:1448-54.
21. O'Corrigan B, Fournier M, Olver IN, Stockler MR, Whitford H, Toner GC, Thomson DB, Davis ID, Hanning F, Singhal N, Underhill C, Clingan P, McDonald A, Boland A, Grimison P. Australian and New Zealand Urogenital and Prostate Cancer Trials Group. Testosterone deficiency and quality of life in Australasian testicular cancer survivors; a prospective cohort study. Intern Med J. 2014;44:813-7.

22. Willemse PM, Burggraaf J, Hamdy NA, Weijl NI, Vossen CY, van Wulften L, van Steijn-van Tol AQ, Rosendaal FR, Osanto S. Prevalence of the metabolic syndrome and cardiovascular disease risk in chemotherapy-treated testicular germ cell tumour survivors. Br J Cancer. 2013;109:60-7.

23. Huddart RA, Norman A, Moynihan C, Horwich A, Parker C, Nicholls E, Dearnaley DP. Fertility, gonadal and sexual function in survivors of testicular cancer. Br J Cancer. 2005;93:200-7.

24. Johnson DH, Hainsworth JD, Linde RB, Greco FA. Testicular function following combination chemotherapy with cis-platin, vinblastine, and bleomycin. Med Pediatr Oncol. 1984;12:233-8.

25. Stuart NS, Woodroffe CM, Grundy R, Cullen MH. Longterm toxicity of chemotherapy for testicular cancer-the cost of cure. $\mathrm{Br}$ J Cancer. 1990;61:479-84.

26. Bandak M, Aksglaede L, Juul A, Rørth M, Daugaard G. The pituitary-Leydig cell axis before and after orchiectomy in patients with stage I testicular cancer. Eur J Cancer. 2011;47:2585-91.

27. de Haas EC, Altena R, Boezen HM, Zwart N, Smit AJ, Bakker SJ, van Roon AM, Postma A, Wolffenbuttel BH, Hoekstra HJ, van Leeuwen FE, Sleijfer DT, Gietema JA. Early development of the metabolic syndrome after chemotherapy for testicular cancer. Ann Oncol. 2013;24:749-55.

28. Willemse PM, Burggraaf J, Hamdy NA, Weijl NI, Vossen CY, van Wulften L, van Steijn-van Tol AQ, Rosendaal FR, Osanto S. Prevalence of the metabolic syndrome and cardiovascular disease risk in chemotherapy-treated testicular germ cell tumour survivors. Br J Cancer. 2013;9(109):60-7.

29. Huddart RA, Norman A, Shahidi M, Horwich A, Coward D, Nicholls J, Dearnaley DP. Cardiovascular disease as a long-term complication of treatment for testicular cancer. J Clin Oncol. 2003;21:1513-23.

30. Eberhard J, Ståhl O, Cohn-Cedermark G, Cavallin-Ståhl E, Giwercman Y, Rastkhani H, Rylander L, Eberhard-Gran M, Kvist U, Giwercman A. Emotional disorders in testicular cancer survivors in relation to hypogonadism, androgen receptor polymorphism and treatment modality. J Affect Disord. 2010;122:260-6.

31. Caminiti G, Volterrani M, Iellano F, et al. Effect of long-acting testosterone treatment on functional exercise capacity, skeletal muscle performance, insulin resistance and baroflex sensitivity in elderly patients with chronic heart failure: a double-blind, placebo-controlled, randomized study. J Am Coll Cardiol. 2009;54:919-27.

32. Isidori AM, Giannetta E, Greco EA, et al. Effects of testosterone on body composition, body metabolism and serum lipid profile in middle-aged men: a meta-analysis. Clin Endocrinol. 2005;63:280-93.

33. Kapoor D, Goodwin E, Channer KS, et al. Testosterone replacement therapy improves insulin resistance, glycaemic control, visceral adiposity and hypercholesterolaemia in hypogonadal men with type 2 diabetes. Eur J Endocrinol. 2006;154:899-906.

34. Saad F, Aversa A, Isidori AM, et al. Onset of effects of testosterone treatment and time span until maximum effects are achieved. Eur J Endocr. 2011;165:675-85.

35. Tracz MJ, Sideras K, Bolona ER, et al. Testosterone use in men and its effects on bone health. A systematic review and metaanalysis of randomized placebo-controlled trials. J Clin Endocrinol Metab. 2006;9:2011-6.

36. du Moon G, Park MG, Lee SW, et al. The efficacy and safety of testosterone undecanoate $\left(\mathrm{Nebido}^{\circledR}\right)$ in testosterone deficiency 
syndrome in Korean: a multicenter prospective study. J Sex Med. 2010;7:2253-60.

37. Giltay EJ, Tishova YA, Mskhalaya GJ, et al. Effects of testosterone supplementation on depressive symptoms and sexual dysfunction in men with metabolic syndrome. J Sex Med. 2010;7:2572-82.

38. Zitzmann M, Weckesser M, Schoner O, et al. Changes in cerebral glucose metabolism and visuospatial capability in hypogonadal males under testosterone substitution therapy. Exp Clin Endocrinol Diabetes. 2001;109:302-4.

39. Parker C, Gillessen S, Heidenreich A, Horwich A. ESMO Guidelines Committe: cancer of the prostate: ESMO Clinical Practice Guidelines for diagnosis, treatment and follow-up. Ann Oncol. 2015;26:v69-77.

40. Mottet N, Bellmunt J, Briers E, et al. Guidelines on prostate cancer. Eur Assoc Urol. 2015. Available online at:http://uroweb. org/guideline/prostate-cancer/

41. Braga-Basaria M, Dobs AS, Muller DC, et al. Metabolic syndrome in men with prostate cancer undergoing long-term androgen-deprivation therapy. J Clin Oncol. 2006;24:3979-83.

42. Valverde J, Planas Morin J, Salvador Lacambra C, et al. Prevalence of metabolic syndrome in prostate cancer patients under androgen-deprivation therapy: interim results of a case-control study. Eur Urol Suppl. 2011;10:337.

43. Keating NL, O’Malley AJ, Freedland SJ, et al. Diabetes and cardiovascular disease during androgen-deprivation therapy: observational study of veterans with prostate cancer. J Natl Cancer Inst. 2010;102:39-46.

44. Bo JJ, Zhang C, Zhang LH, et al. Androgen-deprivation therapy through bilateral orchiectomy: increased metabolic risks. Asian J Androl. 2011;13:833-7.

45. Rezaei MM, Rezaei MM, Ghoreifi A, Kerigh BF. Metabolic syndrome in patients with prostate cancer undergoing intermittent androgen-deprivation therapy. Can Urol Assoc J. 2016;10:E300-5.

46. Bosco C, Crawley D, Adolfsson J, et al. Quantifying the evidence for the risk of metabolic syndrome and its components following androgen-deprivation therapy for prostate cancer: a meta-analysis. PLoS ONE. 2015;10:e0117344.

47. Smith MR, Lee H, Fallon MA, Nathan DM. Adipocytokines, obesity, and insulin resistance during combined androgen blockade for prostate cancer. Urology. 2008;71:318.

48. Davis MK, Rajala JL, Tyldesley S, et al. The prevalence of cardiac risk factors in men with localized prostate cancer undergoing androgen-deprivation therapy in British Columbia, Canada. J Oncol. 2015;2015:820403.

49. Dockery F, Bulpitt CJ, Agarwal S, Donaldson M, Rajkumar C. Testosterone suppression in men with prostate cancer leads to an increase in arterial stiffness and hyperinsulinaemia. Clin Sci. 2003;104:195-201.

50. Tsai HK, D'Amico AV, Sadetsky N, et al. Androgen-deprivation therapy for localized prostate cancer and the risk of cardiovascular mortality. J Natl Cancer Inst. 2007;99:1516-24.

51. Alibhai SM, Duong-Hua M, Sutradhar R, et al. Impact of androgen-deprivation therapy on cardiovascular disease and diabetes. J Clin Oncol. 2009;27:3452-8.

52. Efstathiou JA, Bae K, Shipley WU, et al. Cardiovascular mortality and duration of androgen-deprivation for locally advanced prostate cancer: analysis of RTOG 92-02. Eur Urol. 2008;54:816-23.

53. Kim J, Vaid M, Tyldesley S, et al. Population-based study of cardiovascular mortality among patients with prostate cancer treated with radical external bean radiation therapy with and without adjuvant androgen-deprivation therapy at the British Columbia Cancer Agency. Int J Radiat Oncol Biol Phys. 2011;80:742-50.
54. Punnen S, Cooperberg MR, Sadetsky N, et al. Androgen-deprivation therapy and cardiovascular risk. J Clin Oncol. 2011;29:3510-6.

55. Nguyen TM, Pastuszak AW. Testosterone therapy among prostate cancer survivors. Sex Med Rev. 2016;4:376-88.

56. Albertsen PC, Klotz L, Tombal B, Grady J, Olesen TK, Nilsson J. Cardiovascular morbidity associated with gonadotropin releasing hormone agonists and an antagonist. Eur Urol. 2014;65:565-73.

57. Baumann FT, Zopf EM, Bloch W. Clinical exercise interventions in prostate cancer patients - a systematic review of randomized controlled trials. Support Care Cancer. 2012;20:221-33.

58. Nobes JP, Langley SE, Klopper T, Russell-Jones D, Laing RW. A prospective, randomized pilot study evaluating the effects of metformin and lifestyle intervention on patients with prostate cancer receiving androgen deprivation therapy. BJU Int. 2011;109:1495-502.

59. Shahinian VB, Kuo YF, Freeman JL, Goodwin JS. Risk of the "androgen deprivation syndrome" in men receiving androgen deprivation for prostate cancer. Arch Intern Med. 2006;166:465-71.

60. Morote J, Morin JP, Orsola A, Abascal JM, Salvador C, Trilla E, Raventos CX, Cecchini L, Encabo G, Reventos J. Prevalence of osteoporosis during long-term androgen deprivation therapy in patients with prostate cancer. Urology. 2007;69:500-4.

61. Serpa Neto A, Tobias-Machado M, Esteves MA, Senra MD, Wroclawski ML, Fonseca FL, Dos Reis RB, Pompeo AC. Giglio $\mathrm{AD}$ Bisphosphonate therapy in patients under androgen deprivation therapy for prostate cancer: a systematic review and metaanalysis. Prostate Cancer Prostatic Dis. 2012;15:36-44.

62. Lipton A, Fizazi K, Stopeck AT, Henry DH, Smith MR, Shore N, Martin M, Vadhan-Raj S, Brown JE, Richardson GE, Saad F, Yardley DA, Zhou K, Balakumaran A, Braun A. Effect of denosumab versus zoledronic acid in preventing skeletal-related events in patients with bone metastases by baseline characteristics. Eur J Cancer. 2016;53:75-83.

63. Langdahl BL, Teglbjærg CS, Ho PR, Chapurlat R, Czerwinski E, Kendler DL, Reginster JY, Kivitz A, Lewiecki EM, Miller PD, Bolognese MA, McClung MR, Bone HG, Ljunggren Ö, Abrahamsen B, Gruntmanis U, Yang YC, Wagman RB, Mirza F, Siddhanti S, Orwoll E. A 24-month study evaluating the efficacy and safety of denosumab for the treatment of men with low bone mineral density: results from the ADAMO trial. J Clin Endocrinol Metab. 2015;100:1335-42.

64. Choo R, Chander S, Danjoux C, Morton G, Pearce A, et al. How are hemoglobin levels affected by androgen deprivation in nonmetastatic prostate cancer patients. Can J Urol. 2005;12:2547-52.

65. Strum SB, McDermed JE, Scholz MC, Johnson H, Tisman G. Anaemia associated with androgen deprivation in patients with prostate cancer receiving combined hormone blockade. Br J Urol. 1997;79:933-41.

66. Joly F, Alibhai SM, Galica J, Park A, Yi QL, et al. Impact of androgen deprivation therapy on physical and cognitive function, as well as quality of life of patients with nonmetastatic prostate cancer. J Urol. 2006;176:2443-7.

67. Frisk J. Managing hot flushes in men after prostate cancer-a systematic review. Maturitas. 2010;65:15.

68. Sharifi N, Gulley JL, Dahut WL. Androgen deprivation therapy for prostate cancer. JAMA. 2005;294:238.

69. Gonzalez BD, Jim HS, Donovan KA, Small BJ, Sutton SK, Park J, Lin HY, Spiess PE, Fishman MN, Jacobsen PB. Course and moderators of hot flash interference during androgen deprivation therapy for prostate cancer: a matched comparison. J Urol. 2015;194:690-5.

70. Mohile SG, Mustian K, Bylow K, Hall W, Dale W. Management of complications of androgen deprivation therapy in the older man. Crit Rev Oncol Hematol. 2009;70:235-55. 
71. Irani J, Salomon L, Oba R, Bouchard P, Mottet N. Efficacy of venlafaxine, medroxyprogesterone acetate, and cyproterone acetate for the treatment of vasomotor hot flushes in men taking gonadotropin-releasing hormone analogues for prostate cancer: a double-blind, randomised trial. Lancet Oncol. 2010;11:147-54.

72. Moraska AR, Atherton PJ, Szydlo DW, et al. Gabapentin for the management of hot flashes in prostate cancer survivors: a longitudinal continuation Study-NCCTG Trial N00CB. J Support Oncol. 2010;8:128-32.

73. Feng L, Chen MK, Lukkahatai N, Hsiao CP, Kaushal A, Sechrest L, Saligan LN. Clinical predictors of fatigue in men with nonmetastatic prostate cancer receiving external beam radiation therapy. Clin J Oncol Nurs. 2015;19:744-50.

74. Nelson AM, Gonzalez BD, Jim HS, Cessna JM, Sutton SK, Small BJ, Fishman MN, Zachariah B. Jacobsen PB Characteristics and predictors of fatigue among men receiving androgen deprivation therapy for prostate cancer: a controlled comparison. Support Care Cancer. 2016;24:4159-66.

75. Sharp L, O'Leary E, Kinnear H, Gavin A, Drummond FJ. Cancerrelated symptoms predict psychological wellbeing among prostate cancer survivors: results from the PiCTure study. Psychooncology. 2016;25:282-91.

76. Alibhai SMH, Breunis H, Timilshina N, et al. Impact of androgen-deprivation therapy on cognitive function in men with nonmetastatic prostate cancer. J Clin Oncol. 2010;28:5030-57.

77. Wiechno PJ, Sadowska M, Kalinowski T, Michalski W, Demkow T. Does pharmacological castration as adjuvant therapy for prostate cancer after radiotherapy affect anxiety and depression levels, cognitive functions and quality of life? Psychooncology. 2013;22:346-51

78. McGinty HL, Phillips KM, Jim HS, et al. Cognitive functioning in men receiving androgen deprivation therapy for prostate cancer: a systematic review and meta-analysis. Support Care Cancer. 2014;22:2271-80.

79. Dinh KT, Reznor G, Muralidhar V, Mahal BA, Nezolosky MD, Choueiri TK, Hoffman KE, Hu JC, Sweeney CJ, Trinh QD, Nguyen PL. Association of androgen deprivation therapy with depression in localized prostate cancer. J Clin Oncol. 2016;34:1905-12.

80. Kushnir T, Gofrit ON, Elkayam R, Paluch-Shimon S, Lawrence YR, Weiss L, Symon Z. Impact of Androgen deprivation therapy on sexual and hormonal function in patients receiving radiation therapy for prostate cancer. Isr Med Assoc J. 2016;18:49-53.

81. Ng E, Woo HH, Turner S, Leong E, Jackson M, Spry N. The influence of testosterone suppression and recovery on sexual function in men with prostate cancer: observations from prospective study in men undergoing intermittent androgen suppression. J Urol. 2012;187:2162-6.

82. Elliott S, Latini DM, Walker LM, Wassersug R, Robinson JW. ADT Survivorship Working Group Androgen deprivation therapy for prostate cancer: recommendations to improve patient and partner quality of life. J Sex Med. 2010;7:2996-3010.

83. Brungs D, Chen J, Masson P, Epstein RJ. Intermittent androgen deprivation is a rational standard-of-care treatment for all stages of progressive prostatecancer: results from a systematic review and meta-analysis. Prostate Cancer Prostatic Dis. 2014;17: $105-11$.
84. Hussain M, Tangen CM, Higano CS, et al. Intermittent (IAD) versus continuous androgen deprivation (CAD) in hormone sensitive metastatic prostate cancer (HSM1PC) patients (pts): results of S9346 (INT-0162), an international phase III trial. N Engl J Med. 2013;368:1314-25.

85. International Agency for Research on Cancer, World Healt Organization: GLOBOCAN 2012: Estimated cancerIncidence, Mortality and Prevalence Worlswide in 2012. http://globocan. iarc.fr/Pages/fact_sheets_cancer.aspx.

86. Dev R, Hui D, Del Fabbro E, Delgado-Guay MO, Sobti N, Dalal S, Bruera E. Association between hypogonadism, symptom burden, and survival in male patients with advanced cancer. Cancer. 2014;120:1586-93.

87. Rajagopal A, Vassilopoulou-Sellin R, Palmer JL, Kaur G, Bruera E. Symptomatic hypogonadism in male survivors of cancer with chronic exposure to opioids. Cancer. 2004;100:851-8.

88. Burney BO, Hayes TG, Smiechowska J, et al. Low testosterone levels and increased inflammatory markers in patients with cancer and relationship with cachexia. J Clin Endocrinol Metab. 2012;97:E700-9.

89. Garcia JM, Li H, Mann D, Epner D, Hayes TG, Marcelli M, et al. Hypogonadism in male patients with cancer. Cancer. 2006;106:2583-91.

90. Skipworth RJ, Moses AG, Sangster K, Sturgeon CM, Voss AC, Fallon MT, et al. Interaction of gonadal status with systemic inflammation and opioid use in determining nutritional status and prognosis in advanced pancreatic cancer. Support Care Cancer. 2011;19:391-401.

91. Pimpinelli F, Parenti M, Guzzi F, Piva F, Hokfelt T, Maggi R. Presence of delta opioid receptors on a subset of hypothalamic gonadotropin releasing hormone $(\mathrm{GnRH})$ neurons. Brain Res. 2006;1070:15-23.

92. Mendelson JH, Ellingboe J, Judson BA, Goldstein A. Plasma testosterone and luteinizing hormone levels during levo-alphaacetylmethadol maintenance and withdrawal. Clin Pharmacol Ther. 1984;35:545-7.

93. Howell SJ, Radford JA, Ryder WD, Shalet SM. Testicular function after cytotoxic chemotherapy: evidence of Leydig cell insufficiency. J Clin Oncol. 1999;17:1493-8.

94. Smiechowska J, Utech A, Taffet G, Hayes T, Marcelli M, Garcia $\mathrm{JM}$. Adipokines in patients with cancer anorexia and cachexia. J Investig Med. 2010;58:554-9.

95. Loprinzi CL, Kugler JW, Sloan JA, Mailliard JA, Krook JE, Wilwerding $\mathrm{MB}$, et al. Randomized comparison of megestrol acetate versus dexamethasone versus fluoxymesterone for the treatment of cancer anorexia/cachexia. J Clin Oncol. 1999; 17:3299-306.

96. Del Fabbro E, Garcia JM, Dev R, et al. Testosterone replacement for fatigue in hypogonadal ambulatory males with advanced cancer: a preliminary double-blind placebo-controlled trial. Support Care Cancer. 2013;21(9):2599-607.

97. Kalinchenko SY, Tishova YA, Mskhalaya GJ, Gooren LJ, Giltay EJ, Saad F. Effects of testosterone supplementation on markers of the metabolic syndrome and inflammation in hypogonadal men with the metabolic syndrome: the double-blinded placebo-controlled Moscow study. Clin Endocrinol. 2010;73:602-12. 